\title{
Thermal stability and precipitation strengthening of fully lamellar Ti-45Al-5Nb-0.2B-0.75C alloy
}

\author{
T. Cegan*, I. Szurman \\ VŠB-Technical University of Ostrava, Faculty of Metallurgy and Materials Engineering, Department of RMSTC, \\ 17. listopadu 15, 70833 Ostrava - Poruba, Czech Republic
}

Received 1 October 2017, received in revised form 10 October 2017, accepted 3 November 2017

\begin{abstract}
The alloy with a composition Ti-45Al-5Nb-0.2B-0.75C (at.\%) was prepared by induction melting and centrifugal casting. The fully lamellar microstructure of the alloy without carbides was produced by heat treatment consisting of hot isostatic pressing (HIP) and solution annealing followed by cooling to room temperature. The stability of the fully lamellar $\gamma(\mathrm{TiAl})$ $+\alpha_{2}\left(\mathrm{Ti}_{3} \mathrm{Al}\right)$ microstructure was studied at temperatures of 750,850 and $950{ }^{\circ} \mathrm{C}$ up to an ageing time of $3400 \mathrm{~h}$. The microstructure analysis shows that the most dominant change in the microstructure was the $\alpha_{2}$ lamellae thinning, which was more pronounced at a higher ageing temperature and longer time. The formation of recrystallized $\gamma$ grains and $\mathrm{Ti}_{2} \mathrm{AlC}$ carbides was observed during ageing at the temperatures of 850 and $950^{\circ} \mathrm{C}$. The microstructural changes affected the microhardness at room temperature (RT) and compression yield strength at temperatures ranging from $\mathrm{RT}$ to $950^{\circ} \mathrm{C}$.
\end{abstract}

K e y w o r d s: titanium aluminides, thermal stability, microstructure, carbides, yield strength

\section{Introduction}

TiAl-based alloys have attracted extensive attention as candidates of the next generation hightemperature materials in aerospace and automobile applications due to their low density, excellent corrosion, creep resistance and high specific strength. These alloys are expected to reach the operating temperature above $700-750{ }^{\circ} \mathrm{C}$ with a more excellent elastic modulus and creep resistant properties as compared to those of titanium alloys. Meanwhile, the comprehensive performance of TiAl alloys can even match the performance of Ni-based superalloys, while the density is only half of the latter [1-7]. To extend the service range of TiAl alloys to high strength and temperature, the alloying technique has been proven to be an effective way to improve the performance of TiAl alloys. Probably the most beneficial element for mechanical properties of TiAl alloys is niobium. Significant strengthening can be achieved when $\mathrm{Nb}$ is added to polycrystalline two-phase TiAl alloys because it leads to an increase in the volume fraction of $\alpha_{2}\left(\mathrm{Ti}_{3} \mathrm{Al}\right)$ phase, retardation of diffusion processes during op- erating temperatures and the refinement of the microstructure. $\mathrm{Nb}$ addition also improves oxidation resistance due to modification of the structure of the oxidation layer and decreases the stacking fault energy in the $\gamma(\mathrm{TiAl})$ phase which facilitates twinning, and according to Appel et al. [4] apparently compensates the lack of independent slip systems [4, 8-10]. Depending on the alloy composition and processing parameters, various microstructures can be obtained, and their high-temperature strength level varies with microstructure type and grain size with the brittleductile transition temperature (BDT) from $600^{\circ} \mathrm{C}$ for fine duplex material to $800^{\circ} \mathrm{C}$ for coarse fully lamellar material [9]. The increase of creep resistance for fully lamellar materials can be explained by large grains and by highly anisotropic lath structure inside the grains $[9,11,12]$. However, their inherent poor ductility at room temperature and insufficient strength at high temperatures (above $800^{\circ} \mathrm{C}$ ) limit their widescale applications. A further possibility for increasing the creep resistance can be achieved by an optimization of their chemical composition through the solid solution and precipitation hardening.

\footnotetext{
*Corresponding author: tel.: +420 597329 392; e-mail address: tomas.cegan@vsb.cz
} 
In recent years, the effect of carbon on TiAl alloys has been received considerable attention. Several studies have been focused on the improvement of mechanical properties and creep resistance in the carbon-doped TiAl alloys, and it has been proven that improvement of mechanical properties relates to the solid solution hardening and precipitation hardening [13-22]. Also, the addition of carbon to lamellar TiAl-based alloys can also reduce lamellar space effectively [19]. For high C concentration, carbide precipitation occurs in connection with grain size reduction, but the minimum values of $\mathrm{C}$ content necessary to obtain carbide precipitation strongly depend on the chemical composition of the alloy, thermal processing and microstructure [20, 21]. Coherent $\mathrm{Ti}_{3} \mathrm{AlC}$ (P-type) particles are mostly formed for lower carbon contents at temperatures up to about $750-950^{\circ} \mathrm{C}[20-22]$ and incoherent $\mathrm{Ti}_{2} \mathrm{AlC}$ (H-type) carbides for higher carbon contents at higher temperatures or at longer times. However, most of the carbon added alloys include both types of carbides [21-23]. The driving force for the precipitation process is the limited solubility of carbon, and as generally observed on other alloys, the shape, size and distribution of precipitates are the main factors determining the mechanical properties. In spite of the previous studies which dealt with precipitation of carbides in TiAl alloys [10, 13-28], information about the microstructural stability of carbon added alloys at higher temperatures and longer times is still lacking in the literature. Therefore, this article aims to study the long-term microstructural stability of the Ti-45Al$-5 \mathrm{Nb}-0.2 \mathrm{~B}-0.75 \mathrm{C}$ (at.\%) alloy and effect of microstructural changes on mechanical properties during longterm ageing at temperatures of 750,850 and $950^{\circ} \mathrm{C}$ was evaluated and discussed. The additional objective of present work is to investigate the age hardening behaviour of mentioned alloy and assess the possibilities of increasing the yield strength by precipitating of the carbides.

\section{Experiment}

\section{1. Alloy preparation and heat treatments}

The Ti-45Al-5Nb-0.2B-0.75C alloy (at.\%) was produced using a medium frequency vacuum induction melting furnace Supercast-titan. Pure metals (4N) and $\mathrm{Nb}-\mathrm{Al}$ master alloy were used as a charge. The measured oxygen content in the alloy was around 500 wt. ppm (0.13 at.\%). The as-cast cylindrical bars with a diameter of $20 \mathrm{~mm}$ and length of $225 \mathrm{~mm}$ were subjected to a hot isostatic pressing (HIP) at an applied pressure of $180 \mathrm{MPa}$ and temperature of $1270^{\circ} \mathrm{C}$ for $4 \mathrm{~h}$ to eliminate casting porosity. A fully lamellar $\gamma+\alpha_{2}$ microstructure of the bar was produced by heat treatments (HT) consisting of solution annealing and cool- ing to room temperature. The solid solution annealing was performed in a single $\alpha$-phase (Ti-based solid solution with hexagonal crystal structure) field at $1360^{\circ} \mathrm{C}$ for $1 \mathrm{~h}$ followed by cooling at a constant cooling rate of $20^{\circ} \mathrm{C} \mathrm{min}{ }^{-1}$ to $850{ }^{\circ} \mathrm{C}$ under argon atmosphere. The heat treatment was accomplished by cooling to room temperature in air.

\subsection{Ageing}

After the heat treatments, the bar was cut by electro spark machining into small pieces with a diameter of $20 \mathrm{~mm}$ and length of $12 \mathrm{~mm}$. The ageing experiments were performed at three temperatures of 750 , 850 and $950^{\circ} \mathrm{C}$ up to $3400 \mathrm{~h}$ in resistance tube furnaces with a static argon atmosphere. The oxygen content in the alloy after ageing was still around 500 wt. ppm, but there was a slight surface oxidation of the sample, especially when aged at $950^{\circ} \mathrm{C}$. To avoid altering the properties of the alloy with oxygen, each sample was cut half, and the cut surface was analysed after ageing.

\subsection{Characterization of microstructure and mechanical properties}

The samples were observed by optical microscopy (OM) on the microscope Olympus GX51 equipped with digital camera Olympus DP12 (OM), scanning electron microscopy in the mode of back-scattered electrons (BSEM) using microscopes QUANTA FEG 450 and JSM-7600F equipped with an energy dispersive spectrometer (EDS) and by X-ray diffraction (XRD). Transmission electron microscopy (TEM) was performed by JEM-2100 microscope operating at $200 \mathrm{kV}$. Samples for TEM with an initial thickness of $0.3 \mathrm{~mm}$ were thinned mechanically by grinding to a thickness of $100 \mu \mathrm{m}$ and finally thinned electrolytically in electrolyte A3 Struers using TenuPol-3 device operating at a voltage of $20 \mathrm{~V}$ and a solution temperature of $-20^{\circ} \mathrm{C}$. Oxygen and carbon contents were measured by the thermo-evolution method by analysers ELTRA ONH-2000 and ELTRA CS-2000, respectively. The quantitative metallographic analysis was performed on digitalized micrographs using a computerized image analyser SigmaScanPro. For determination of the average lamellar thickness, inter-lamellar spacing and the determination of their distribution at least 1000 individual lamellae in at least 20 different grains were measured for each sample using BSEM images. For determination of the $\alpha_{2}$-phase content at least 20 digitalized images were measured. Vickers microhardness measurements were performed at a constant load of $1 \mathrm{~N}$ for loading time of $10 \mathrm{~s}$ on polished and slightly etched samples. The microhardness measurement was carried out with the order of the measured points in the matrix and for each sample at least 

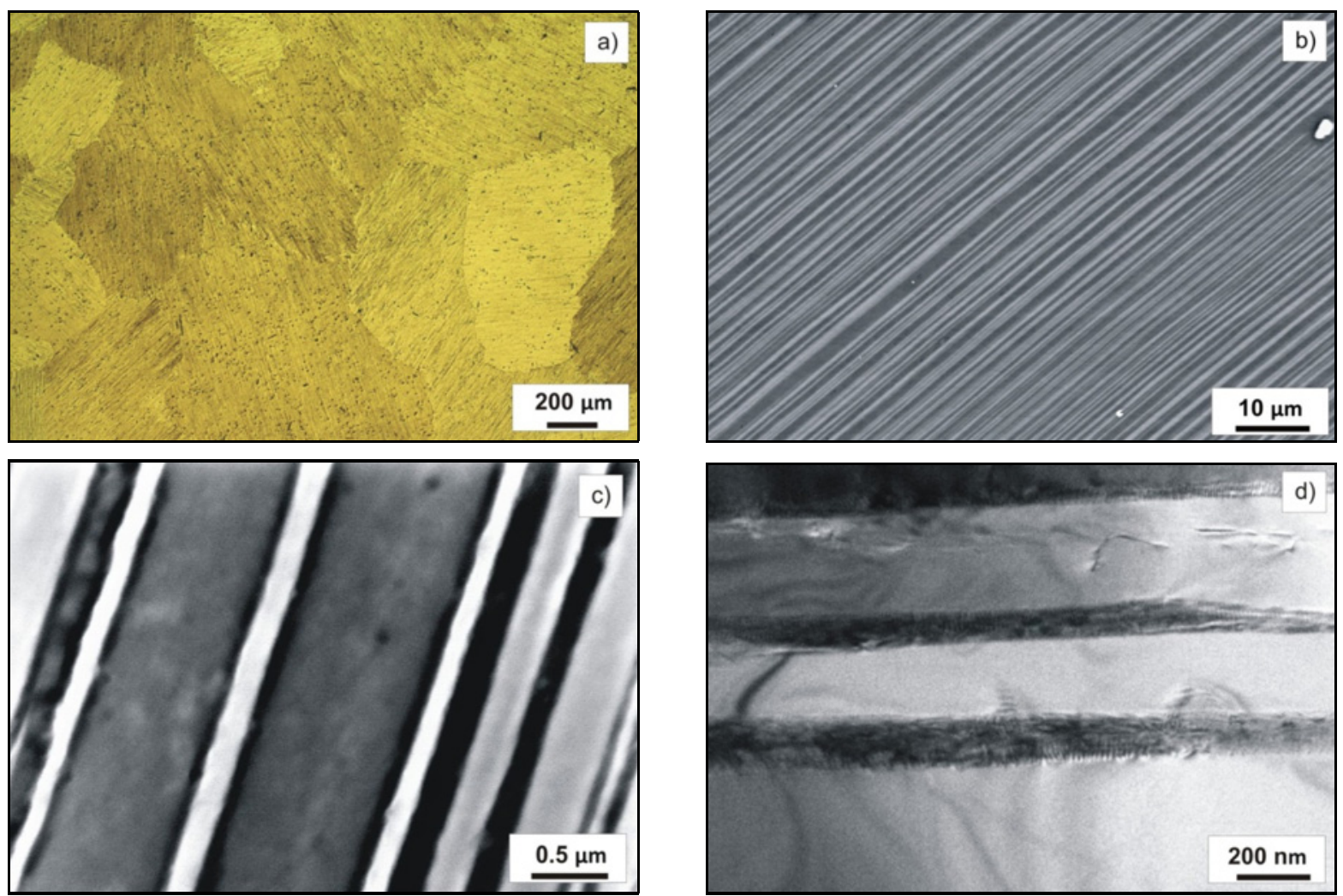

Fig. 1. Micrographs showing microstructure of Ti-45Al-5Nb-0.2B-0.75C alloy after HT: (a) OM; (b, c) BSEM; (d) TEM-bright field.

60 individual indentations. Room temperature compression tests were performed at an initial straining rate of $0.025 \mathrm{~s}^{-1}$. Compression specimens with a diameter of $4 \mathrm{~mm}$ and length of $6 \mathrm{~mm}$ were cut from the $\mathrm{HT}$ and aged samples by electric discharge machining and ground using a centre-less grinder. The compression offset yield strength was measured at $0.2 \%$ plastic strain. The yield strength was determined based on at least two compression tests.

\section{Results and discussion}

\subsection{Microstructure of heat-treated alloy before thermal exposure}

Figures $1 \mathrm{a}-\mathrm{d}$ show the microstructure of the alloy after solid solution annealing (HT) followed by cooling at a constant cooling rate of $20^{\circ} \mathrm{C} \mathrm{min}{ }^{-1}$ to $850{ }^{\circ} \mathrm{C}$ and free air cooling to room temperature. The alloy consists of equiaxed grains with an average size about $380 \mu \mathrm{m}$. The microstructure of the grains is fully lamellar, consisting of alternating lamellae of $\gamma$ (in BSEM darker colour) and $\alpha_{2}$-phases (bright colour), and no remained $\beta$-phase (Ti-based solid solution with cubic crystal structure) was observed. Figure 2 shows XRD diffraction pattern of the alloy after HT and summarizes the coexisting phases. Par-

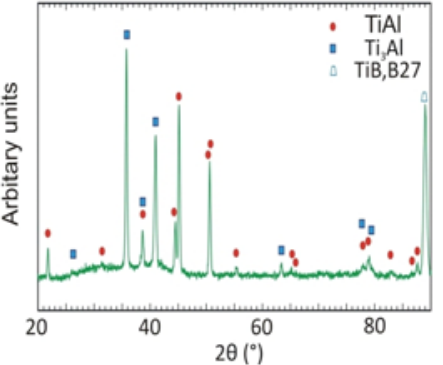

Fig. 2. Diffraction pattern of Ti-45Al-5Nb-0.2B-0.75C alloy after HT.

ticles with ribbon-like morphology (black colour in Fig. 1a and bright colour in Fig. 1b) are identified as $(\mathrm{Ti}, \mathrm{Nb}) \mathrm{B}$ borides in agreement with the observations of a similar type of alloys [29, 30]. The average width of the $\gamma$ and $\alpha_{2}$ lamellae was 0.42 and $0.31 \mu \mathrm{m}$, respectively, and their lamellar thickness frequency distribution can be well fitted by a log-normal distribution function. Quantitative metallographic analysis revealed that the lamellar grains contained about 37 vol. $\%$ of the $\alpha_{2}$-phase and 63 vol. $\%$ of the $\gamma$-phase. These results are in good agreement with the results reported by Schwaighofer et al. [13] that the content of $\alpha_{2}$-phase was just below $40 \%$ for the TNM alloy (Ti-43.5Al-4Nb-1Mo-0.1B) with $0.75 \mathrm{C}$ (at. \%) after HIP 

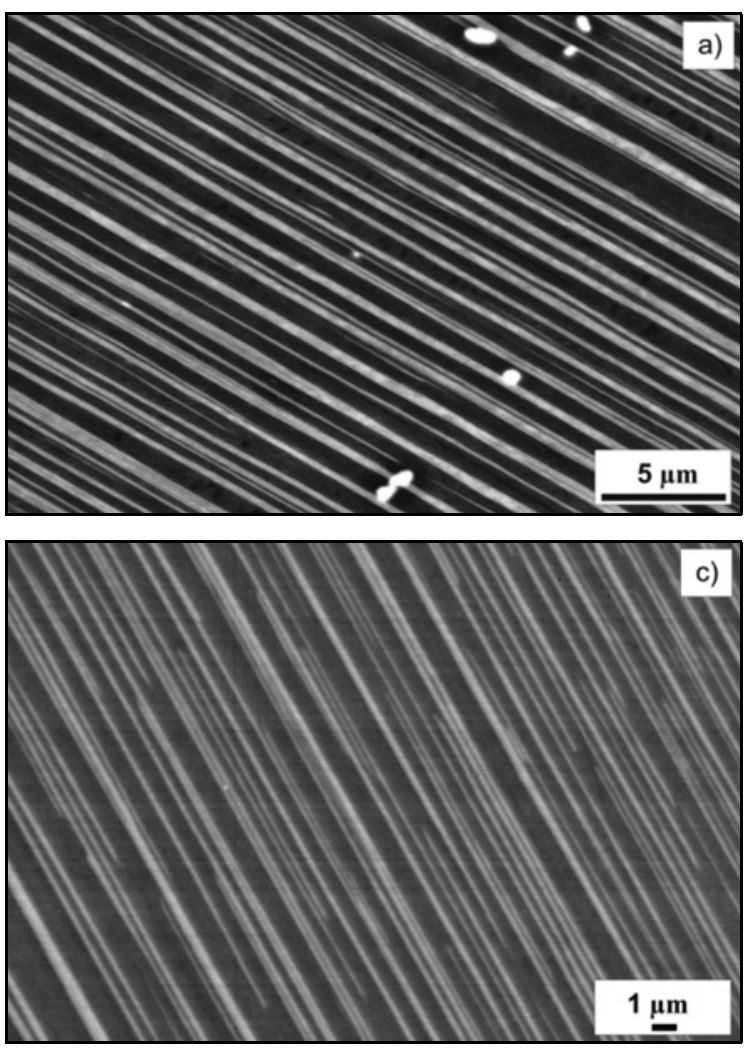
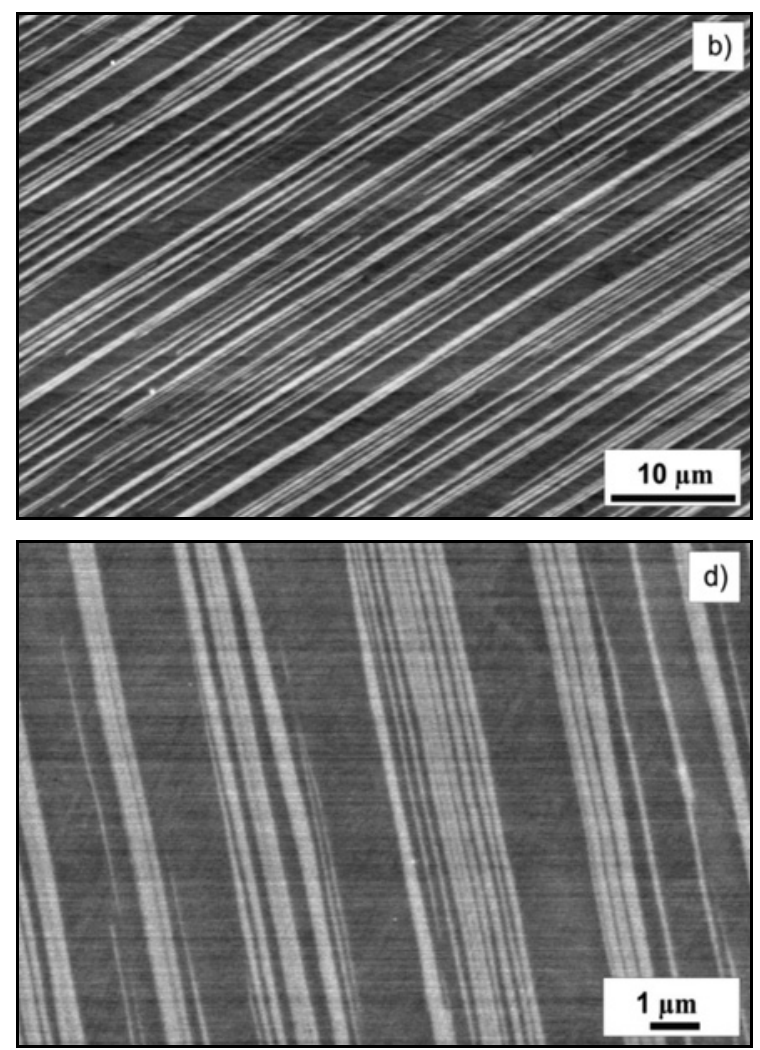

Fig. 3. BSEM micrographs showing microstructure of Ti-45Al-5Nb-0.2B-0.75C alloy after $\mathrm{HT}$ and ageing at (a) $950{ }^{\circ} \mathrm{C}$ for $4 \mathrm{~h}$; (b) $950^{\circ} \mathrm{C}$ for $2000 \mathrm{~h}$; (c) $750^{\circ} \mathrm{C}$ for $3400 \mathrm{~h}$; (d) $850^{\circ} \mathrm{C}$ for $960 \mathrm{~h}$.

at $1200^{\circ} \mathrm{C} / 4 \mathrm{~h} / 200 \mathrm{MPa}$. The relatively high volume fraction of the $\alpha_{2}$-phase can be explained by a stabilizing effect of carbon on the $\alpha_{2}$-phase and relatively high cooling rate $[10,13,14]$. Figure $1 d$ shows TEM bright field image of the alloy after HT. In this figure, the lamellae contain no carbides, which indicates that carbon remained completely dissolved in the $\gamma$ - and $\alpha_{2}$-phases after the applied heat treatment. The absence of the carbides was also confirmed by the results of X-ray diffraction (see Fig. 2).

\subsection{The microstructure of heat-treated alloy after thermal exposure}

\subsubsection{Content of $\alpha_{2}$-phase and lamellar spacing}

Figures $3 \mathrm{a}-\mathrm{d}$ show the microstructure after exposure at $950^{\circ} \mathrm{C}$ for $4 \mathrm{~h}$ (Fig. 3a), $950^{\circ} \mathrm{C}$ for $2000 \mathrm{~h}$ (Fig. 3b), $750^{\circ} \mathrm{C}$ for $3400 \mathrm{~h} \mathrm{(Fig.} \mathrm{3c)} \mathrm{and} 850^{\circ} \mathrm{C}$ for $960 \mathrm{~h}$ (Fig. 3d). The microstructure of the alloy still shows the fully lamellar type of microstructure after ageing at all specified temperatures up to $3400 \mathrm{~h}$. In comparison with Fig. 1b, it can be observed that the dominant change in the lamellar grains is the gradual thinning of the $\alpha_{2}$ lamellae which become discontinuous. The first higher amount of discontinuous and thinned lamellae are observed after $4 \mathrm{~h}$ at $950^{\circ} \mathrm{C}$ and their extent increased with increasing time and temperature. Significant decomposition of the $\alpha_{2}$ lamellae has already started to occur, but not to such a dramatic extent as reported for a fine fully lamellar Ti48Al-2Cr-2Nb-1B alloy (at.\%), where exposure even at $700{ }^{\circ} \mathrm{C}$ for $3000 \mathrm{~h}$ resulted in the almost complete removal of $\alpha_{2}$ [31]. No decomposition of the $\alpha_{2}$ lamellae into $\alpha_{2}+\beta$ and no recrystallization of $\beta$-phase were observed. Only in some thick $\alpha_{2}$ lamellae decomposition into refined $\alpha_{2}+\gamma$ lamellae was detected at all temperatures (see. Fig. 3d). Figure 4 shows the average thickness of the $\alpha_{2}$ lamellae and the volume fraction of $\alpha_{2}$ lamellae after HT and after ageing at 750, 850 and $950{ }^{\circ} \mathrm{C}$ for $3400 \mathrm{~h}$. The average thickness of the $\alpha_{2}$ lamellae decreases by 15, 24 and $29 \%$ at 750 , 850 and $950^{\circ} \mathrm{C}$, respectively. These results are in good agreement with the results of the volume fraction of $\alpha_{2}$ lamellae, which decreases by 12, 21 and $38 \%$ at 750,850 and $950{ }^{\circ} \mathrm{C}$, respectively. The decrease of the volume fraction and average thickness of $\alpha_{2}$ lamellae $(D)$ was calculated according to the relationship:

$$
D=\frac{X_{\mathrm{HT}}-X_{\mathrm{A}}}{X_{\mathrm{HT}}} \times 100
$$

where $X_{\mathrm{HT}}$ is the volume fraction and average thickness before exposure and $X_{\mathrm{A}}$ is the volume fraction and average thickness after exposure. The drop in the 

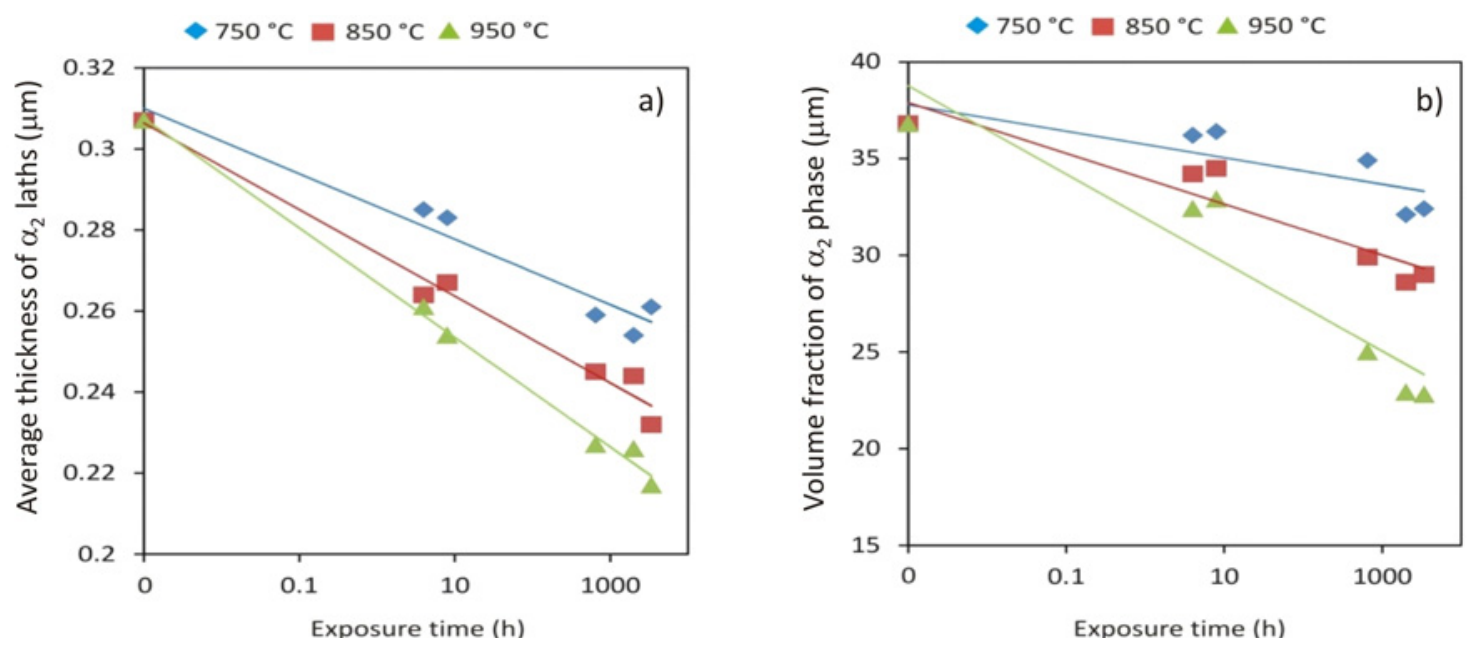

Fig. 4. (a) Measured thickness of $\alpha_{2}$-phase as a function of ageing time and (b) evolution of content of $\alpha_{2}$-phase during ageing.

$\alpha_{2}$ volume fraction during ageing of fully lamellar TiAl alloys is well documented [32-34], and it can easily be explained by the fact that a fine lamellar structure with a large $\alpha_{2}$ volume fraction is stoichiometrically far from the equilibrium and therefore is not stable during the thermal exposure. The retention of the metastable $\alpha_{2}$ before ageing provides a large driving force for its dissolution [32]. The drop in $\alpha_{2}$-phase content is, however, much lower than was reported by Karthikeyan and Mills [32], who reported a decrease of $\alpha_{2}$ content in fully lamellar K5 (Ti-46Al-2Cr-3Nb$-0.2 \mathrm{~W}$ ) and $\mathrm{K} 5 \mathrm{SC}(\mathrm{Ti}-46 \mathrm{Al}-2 \mathrm{Cr}-3 \mathrm{Nb}-0.2 \mathrm{~W}-0.1 \mathrm{C}-0.1 \mathrm{Si})$ alloys from 22 and 29 vol.\% before exposure to 7.2 and 8 vol. $\%$ after exposure at $900{ }^{\circ} \mathrm{C}$ for $24 \mathrm{~h}$, respectively. The low drop in the $\alpha_{2}$-phase content for examined alloy may be related to higher $\mathrm{C}$ content, because carbon is namely known as a distinctive alpha stabilizer in the Ti-Al system, but also by a higher content of niobium and by differences of the applied heat treatments before exposure. Figure 5 shows the comparison of $\alpha_{2}-\alpha_{2}$ inter-lamellar spacing distribution in the sample before exposure and after $3400 \mathrm{~h}$ at 750 , 850 and $950^{\circ} \mathrm{C}$. This figure shows that the highest frequency of the smallest inter-lamellar spacing (smaller than $0.5 \mu \mathrm{m}$ ) was observed in the sample after the exposure at $750^{\circ} \mathrm{C}$, but for larger inter-lamellar spacing (higher than $0.7 \mu \mathrm{m}$ ) there is a higher frequency for the sample before exposure. For samples after $3400 \mathrm{~h}$ of ageing at 850 and $950^{\circ} \mathrm{C}$, the frequency of smaller inter-lamellar spacing decreases and the frequency of higher inter-lamellar spacing increases, respectively. Higher frequencies for small inter-lamellar distances in the sample after exposure at $750^{\circ} \mathrm{C}$ for $3400 \mathrm{~h}$ than for the sample before exposure can be explained by the high incidence of fine lamellae resulting from the decomposition of the coarse $\alpha_{2}$ lamellae into refined $\alpha_{2}+\gamma$ lamellae (see Fig. 3d) and also by a low drop in the content of the $\alpha_{2}$-phase during the exposure at

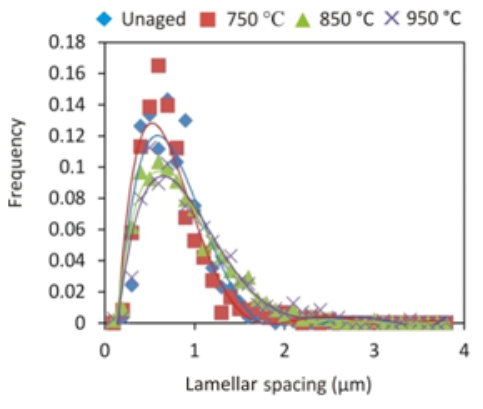

Fig. 5. Distribution of $\alpha_{2}-\alpha_{2}$ inter-lamellar spacing during ageing at 750,850 and $950^{\circ} \mathrm{C}$ for $3400 \mathrm{~h}$.

$750^{\circ} \mathrm{C}$. Average inter-lamellar distances for the individual samples before and after exposure at 750, 850 and $950^{\circ} \mathrm{C}$ for $3400 \mathrm{~h}$ were identified as $0.71,0.83$ and $0.90 \mu \mathrm{m}$, respectively, which means that the average lamellar spacing does not show significant change during ageing at $750^{\circ} \mathrm{C}$ for $3400 \mathrm{~h}$ but increases with the increasing temperature.

\subsubsection{Formation of equiaxed $\gamma$ grains}

Besides parallel decomposition of the $\alpha_{2}$ lamellae, the nucleation and growth of equiaxed $\gamma$ grains at the grain boundaries and also within the lamellar grains can be observed during the ageing experiments. Figure 6 shows the microstructure after ageing at $850^{\circ} \mathrm{C}$ for $2000 \mathrm{~h}$ (Fig. 6a) and $950^{\circ} \mathrm{C}$ for $3400 \mathrm{~h}$ (Fig. 6b), respectively. Several recrystallized equiaxed $\gamma$ grains can be observed especially around the bright boride particles in the lamellar grains and on the grain boundaries. First greater proportions of small recrystallized $\gamma$ grains (up to $5 \mu \mathrm{m}$ ) were observed after ageing at $850^{\circ} \mathrm{C}$ for $960 \mathrm{~h}$ and $950^{\circ} \mathrm{C}$ for $8 \mathrm{~h}$, but usually only on the grain boundaries and exceptionally 

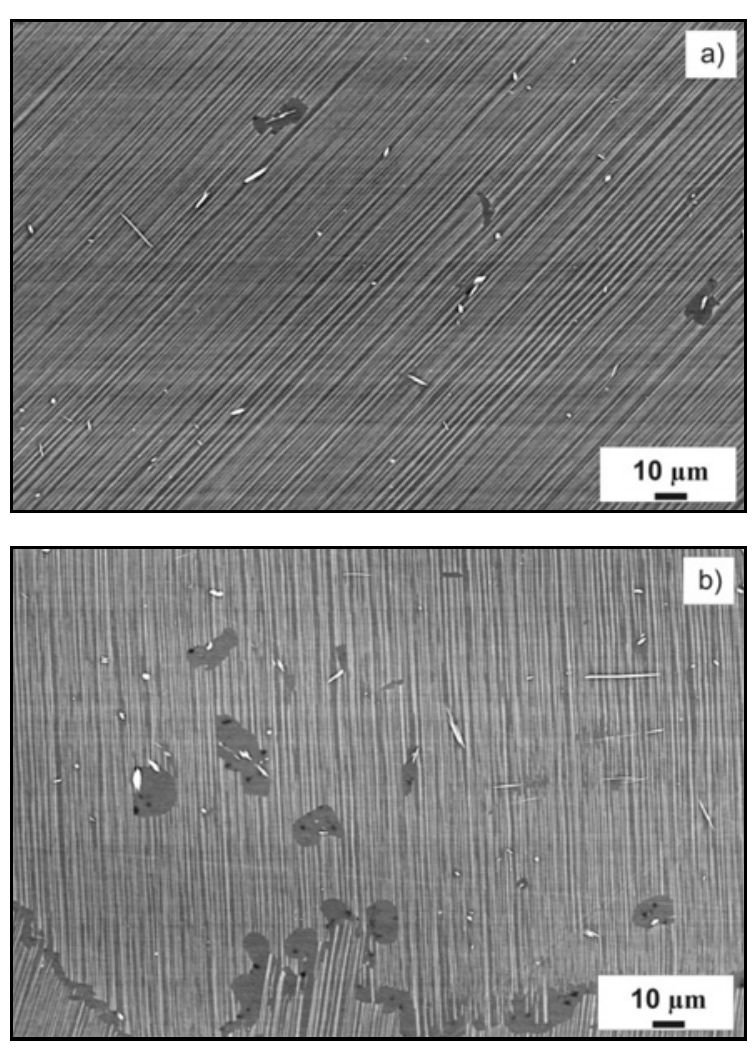

Fig. 6. BSEM micrographs showing microstructure of Ti$-45 \mathrm{Al}-5 \mathrm{Nb}-0.2 \mathrm{~B}-0.75 \mathrm{C}$ alloy after $\mathrm{HT}$ and ageing at (a) $850^{\circ} \mathrm{C}$ for $2000 \mathrm{~h}$; (b) $950^{\circ} \mathrm{C}$ for $3400 \mathrm{~h}$.

inside the grains. For shorter ageing times and for ageing at $750^{\circ} \mathrm{C}$, the equiaxed $\gamma$ grains were only rarely formed at the grain boundaries. The high amount of the recrystallized $\gamma$ grains within the lamellar grains
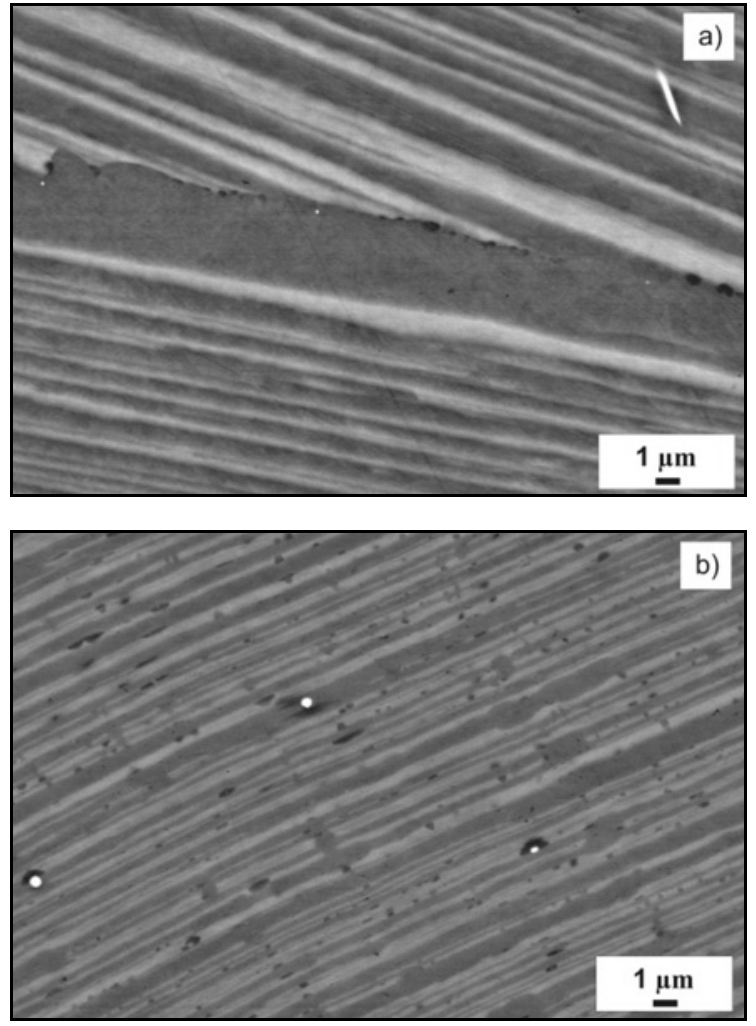

Fig. 7. BSEM micrographs showing microstructure of Ti$-45 \mathrm{Al}-5 \mathrm{Nb}-0.2 \mathrm{~B}-0.75 \mathrm{C}$ alloy after $\mathrm{HT}$ and ageing at (a) $850{ }^{\circ} \mathrm{C}$ for $650 \mathrm{~h}$; (b) $950^{\circ} \mathrm{C}$ for $8 \mathrm{~h}$.

are seen only after the exposure at $850^{\circ} \mathrm{C}$ for $2000 \mathrm{~h}$ (not for shorter times at that temperature) and after exposure at $950^{\circ} \mathrm{C}$ for $960 \mathrm{~h}$ or longer ageing times. The size and frequency of the recrystallized $\gamma$ grains

\section{Niobium La1 Titanium Ka1 Aluminium Ka1 Carbon Ka1}
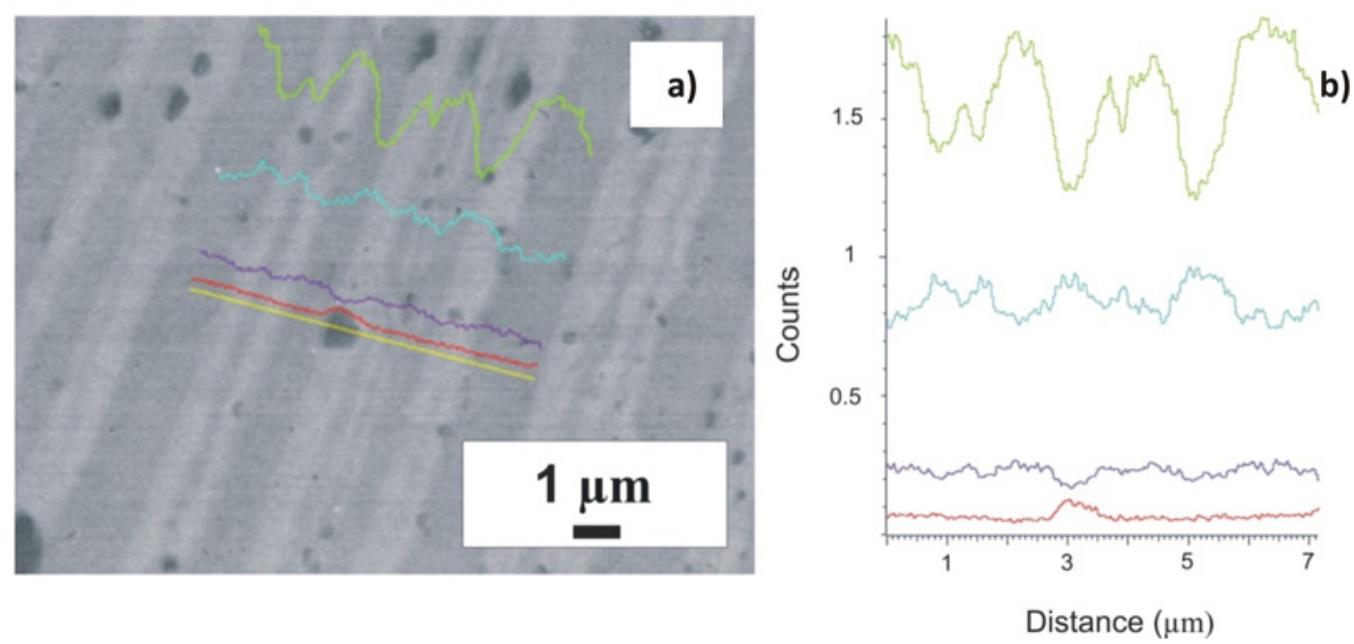

Fig. 8a,b. Precipitate cross-sectional EDS line analysis after ageing at $950^{\circ} \mathrm{C}$ for $8 \mathrm{~h}$. 

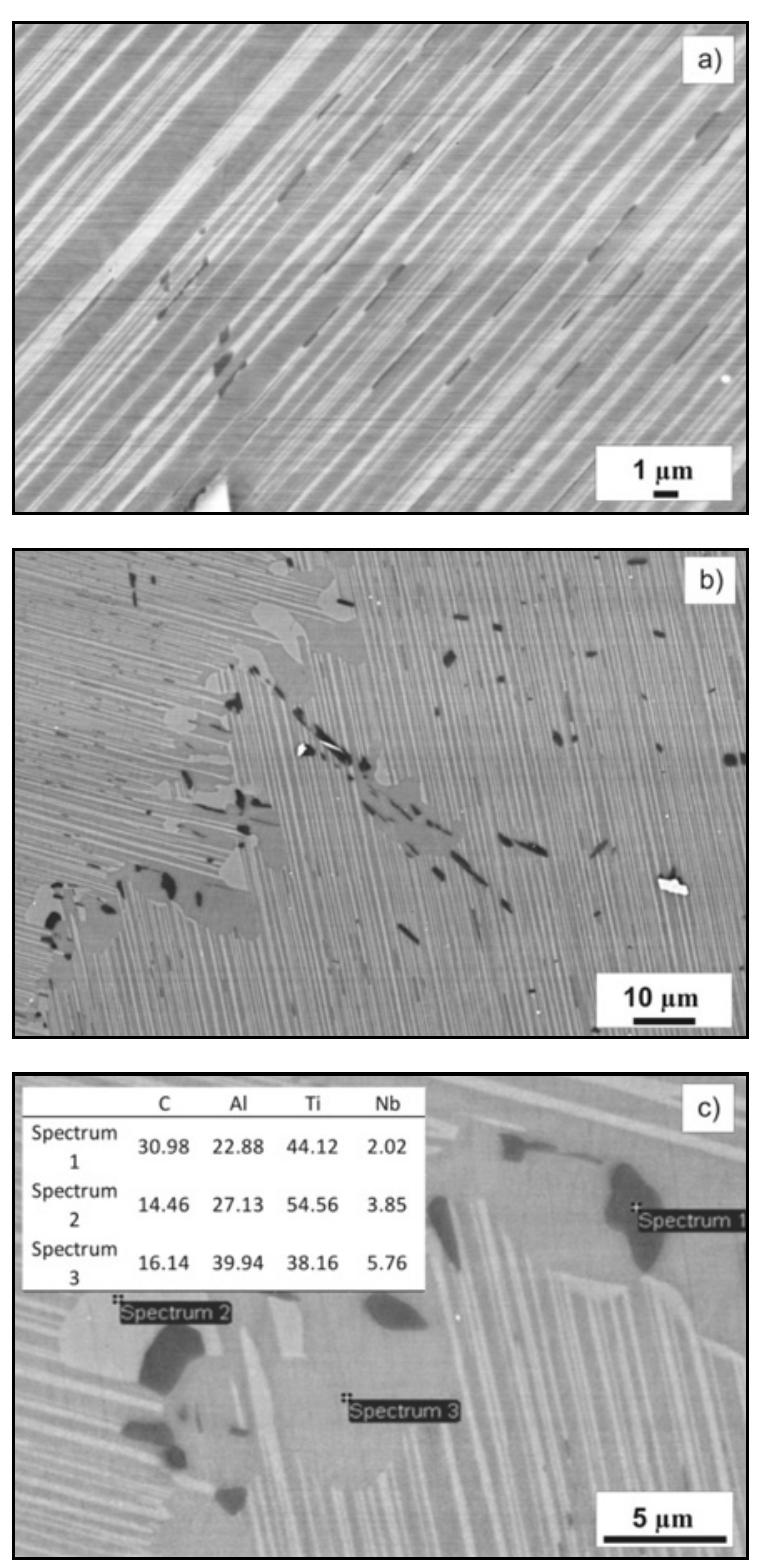

Fig. 9. BSEM micrographs showing microstructure of Ti45Al-5Nb-0.2B-0.75C alloy after $\mathrm{HT}$ and ageing at (a) $850{ }^{\circ} \mathrm{C}$ for $3400 \mathrm{~h}$; (b) $950{ }^{\circ} \mathrm{C}$ for $3400 \mathrm{~h}$; (c) EDS spot analysis of carbide after ageing at $950^{\circ} \mathrm{C}$ for $3400 \mathrm{~h}$.

increase with increasing temperature and time (see Fig. 6b). The amount of the recrystallized $\gamma$ grains is small at $750{ }^{\circ} \mathrm{C}$ even after $3400 \mathrm{~h}$. The formation of the $\gamma$-phase within the $\gamma+\alpha_{2}$ lamellae requires a change in the crystal structure as well as in the concentration of the alloying elements. The formation of the higher amount of the equiaxed $\gamma$ grains indicates microstructure instability at 850 and $950{ }^{\circ} \mathrm{C}$.

\subsubsection{Carbide precipitation}

As can be seen in Fig. 6b, some dark precipitates (easily visible by SEM) were observed in the recrys-

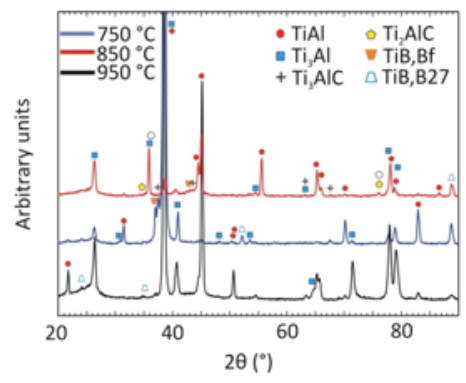

Fig. 10. The diffraction pattern of Ti-45Al-5Nb-0.2B-0.75C alloy after $\mathrm{HT}$ and ageing at 750,850 and $950^{\circ} \mathrm{C}$ for $3400 \mathrm{~h}$.

tallized $\gamma$ grains. The presence of fine dark precipitates was also detected in the lamellar $\gamma+\alpha_{2}$ matrix. The precipitates are observed after the exposure at $850^{\circ} \mathrm{C}$ for $650 \mathrm{~h}$ (see Fig. 7a) mainly on the grain boundaries and at $950^{\circ} \mathrm{C}$ for shorter times (first precipitates after $8 \mathrm{~h}$ on the grain boundaries, but also in lamellar grains, see Fig. 7b). Figure 8 shows precipitate cross-sectional EDS line analysis confirming the presence of the carbides. The EDS spot analysis also confirmed the increased carbon content in the precipitates but did not allow an accurate carbide type determination because of the small carbide size and also of the problematic determination of the exact carbon content by EDS method. Figure 9a shows the carbides in the lamellar grain after ageing at $850^{\circ} \mathrm{C}$ for $3400 \mathrm{~h}$. These precipitates exhibit a needle-like shape and a length of up to $5 \mu \mathrm{m}$ and are mainly formed at the lamellar interfaces and inside the $\alpha_{2}$ lamellae. Figure $9 \mathrm{~b}$ shows the microstructure after ageing at $950^{\circ} \mathrm{C}$ for $3400 \mathrm{~h}$. As can be seen in this figure, the carbides exhibit larger dimensions up to $10 \mu \mathrm{m}$ and wider shape, but precipitates show significant differences for individual grains, indicating the uneven distribution of carbon. EDS spot analysis of carbides (see Fig. 9c) reveals an increased content of $\mathrm{C}$ in the precipitates and the content of $\mathrm{Ti}$ and $\mathrm{Al}$ in the precipitates was approximately $2: 1$ indicating that these particles probably belong to $\mathrm{Ti}_{2} \mathrm{AlC}$ phase, in accordance with Kim and $\mathrm{Kim}$ [35] observations of K5SC alloy after ageing at $900^{\circ} \mathrm{C}$, which identified similar precipitates (clearly observable by SEM) by TEM as $\mathrm{Ti}_{2} \mathrm{AlC}$. Similar results during ageing of the fully lamellar K5SC alloy were also published by Karadge et al. [26]. SEM observations show only a very small amount of $\mathrm{Ti}_{2} \mathrm{AlC}$ carbides after ageing at $850^{\circ} \mathrm{C}$ and practically no carbides at $750^{\circ} \mathrm{C}$. The XRD analysis of the samples aged for $3400 \mathrm{~h}$ shown in Fig. 10 confirms the occurrence of $\mathrm{Ti}_{2} \mathrm{AlC}$ carbides in the microstructure. However, it also shows the presence of carbides $\mathrm{Ti}_{3} \mathrm{AlC}$ (P-type), which is characterized by smaller dimensions and their observations can mostly be made only with TEM. Figure 11 shows TEM bright field image of the microstructure of sample after ageing at $950^{\circ} \mathrm{C}$ for 

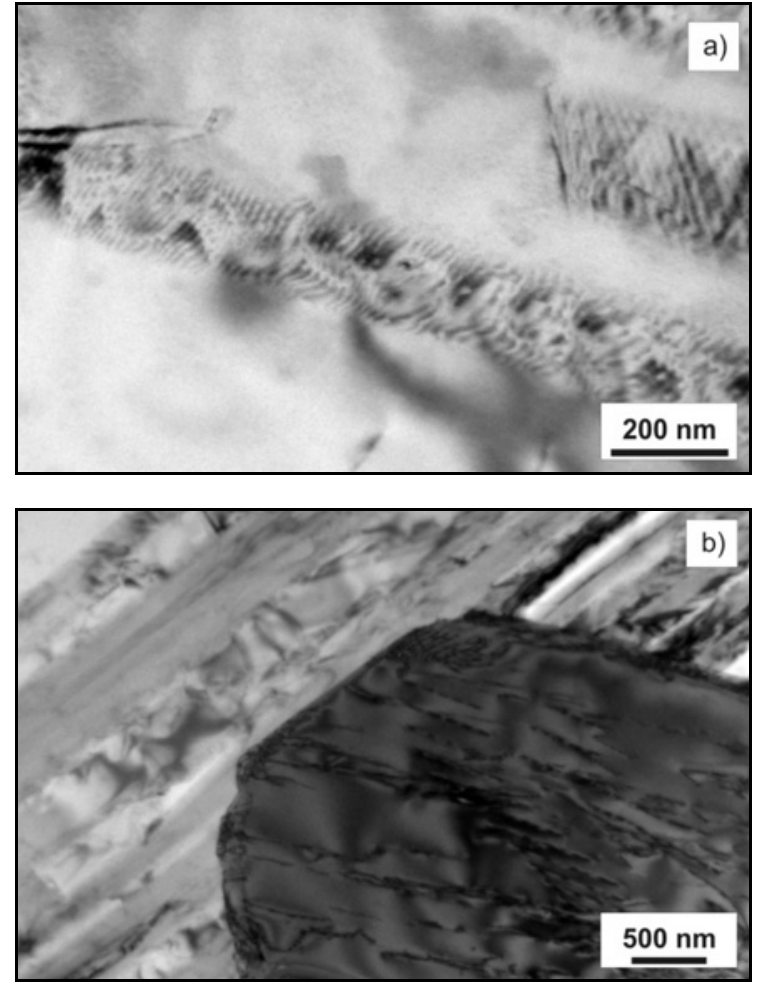

Fig. 11. TEM bright field micrographs showing microstructure of Ti-45Al-5Nb-0.2B-0.75C alloy after HT and ageing at (a) $950^{\circ} \mathrm{C}$ for $8 \mathrm{~h}$; (b) $750^{\circ} \mathrm{C}$ for $14 \mathrm{~h}$.

$8 \mathrm{~h}$ and after ageing at $750^{\circ} \mathrm{C}$ for $14 \mathrm{~h}$. Small carbide precipitates (lower than $500 \mathrm{~nm}$ ) observed in the microstructure were identified as $\mathrm{Ti}_{3} \mathrm{AlC}$ carbides in the alloys with similar chemical composition [20, 21, 25]. These carbides precipitated exclusively on crystallographic defects such as grain boundaries and dislocations due to the heterogeneous type of the nucleation. TEM and SEM observations thus revealed the presence of both types of carbides in the microstructure.

\subsection{Vickers microhardness evolution during ageing}

Figure 12 shows the variation of Vickers microhardness with the ageing time. The typical age hardening (for short ageing times) and softening are observed for all three ageing temperatures. During the age hardening, the microhardness increases with the ageing time. The highest hardening rate was observed at $950^{\circ} \mathrm{C}$ reaching maximum values after $8 \mathrm{~h}$ of ageing. The highest values of microhardness at $850{ }^{\circ} \mathrm{C}$ were detected after $10-12 \mathrm{~h}$ of ageing and after $14 \mathrm{~h}$ of ageing at $750^{\circ} \mathrm{C}$. A similar increase of hardness and yield strength in carbon added $\gamma$-TiAl alloys during ageing was also observed by Tian and Nemoto [15] and Wu et al. [36], who stated that the hardening of the alloy caused precipitation of fine carbides in the TiAl ma-

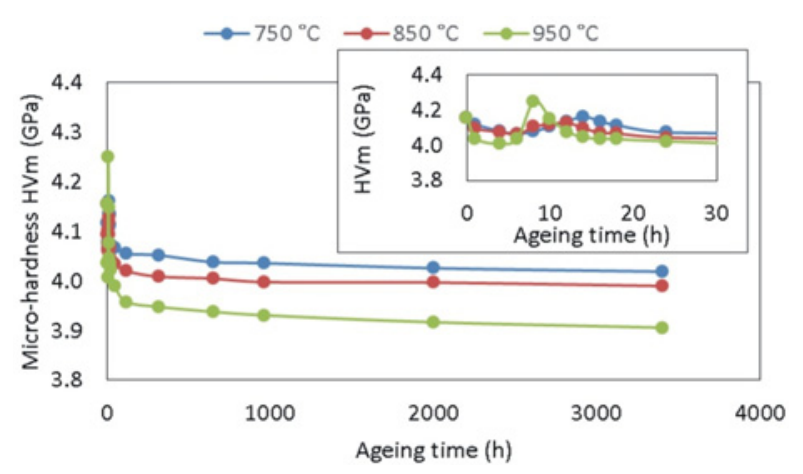

Fig. 12. Variation of Vickers microhardness with the ageing time.

trix. The microhardness values thus firstly increase to peak values, and after reaching maximum values they decrease with increasing temperature, but the decrease is only small of $0.14,0.17$ and $0.25 \mathrm{GPa}$ at 750 , $850,950^{\circ} \mathrm{C}$ for $3400 \mathrm{~h}$, respectively. The drop in the microhardness was much lower than that of $0.54-0.56$ GPa reported by Lapin and Pelachová [37] for lamellar regions in the Ti-45.2Al-2W-0.6Si-0.7B (at.\%) alloy after the exposure at $800{ }^{\circ} \mathrm{C}$ for $3300 \mathrm{~h}$, or that of $1.3 \mathrm{GPa}$ that was reported by Gil et al. [38] for lamellar regions in the Ti-46.5Al-2W-0.5Si (at.\%) alloy after exposure at $975^{\circ} \mathrm{C}$ for $100 \mathrm{~h}$. These results indicate that the softening of Ti-45Al-5Nb-0.2B-0.75C is slower and cannot affect significantly the yield strength of the alloy, because, as reported previously by Lapin et al. [39], Vickers microhardness usually is linearly dependent on the yield strength in lamellar alloys and microhardness can, therefore, may be a simple way to determine the approximate yield strength or changes in the yield strength of TiAl alloys. However, roughing and growth of carbides at higher temperatures appears to be problematic because large carbides in TiAl-based alloys reduce ductility and deteriorate mechanical properties at RT [23, 27].

\subsection{Compression properties}

Figure 13 shows the temperature dependence of compressive yield strength (YS) of the alloy after HT and ageing at $950^{\circ} \mathrm{C}$ for $8 \mathrm{~h}, 850^{\circ} \mathrm{C}$ for $10 \mathrm{~h}$ and $750{ }^{\circ} \mathrm{C}$ for $14 \mathrm{~h}$, respectively. At RT, the YS of the Ti-45Al$-5 \mathrm{Nb}-0.2 \mathrm{~B}-0.75 \mathrm{C}$ alloy ranges around $1020-1070 \mathrm{MPa}$ for the aged samples and about $920 \mathrm{MPa}$ for unaged samples and decreases slightly with increasing temperature to about $740-840 \mathrm{MPa}$ at $800^{\circ} \mathrm{C}$. It can be seen that the yield strength of the studied alloy is relatively high and does not show any significant changes with different ageing conditions. More pronounced differences in the yield strength were found only at RT at which higher strength was found for the samples aged to peak microhardness values. At higher tem- 


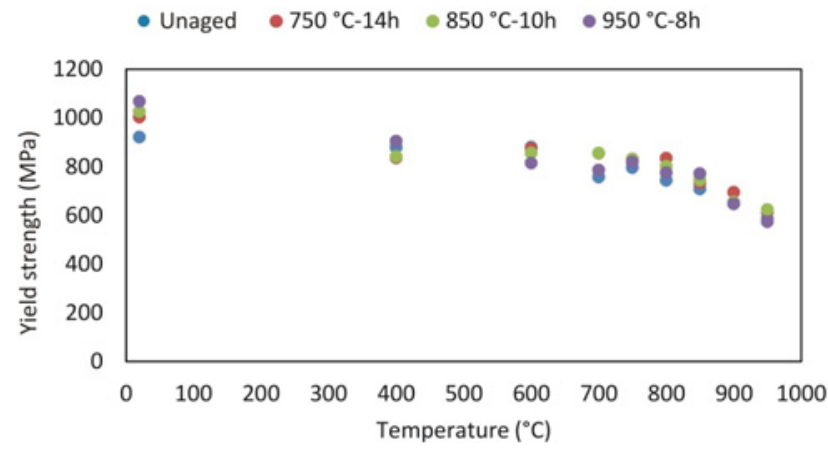

Fig. 13. Temperature dependence of compression yield strength.

peratures, the drop in the yield strength is higher and achieves $570-630 \mathrm{MPa}$ at $950^{\circ} \mathrm{C}$. At these conditions, the samples showed no longer any significant differences at different ageing conditions. The measured yield strengths of the studied alloy are quite high up to $950^{\circ} \mathrm{C}$ and indicate the capability of the fully lamellar microstructure in combination with carbon alloying to operate at high temperatures. For example, one of modern TiAl alloys Ti-46Al-8Ta (at.\%) with fully lamellar microstructure, for which the temperature yield strength dependence was measured by Lapin et al. [40], the compression yield strength was only about $540 \mathrm{MPa}$ at RT and about $450 \mathrm{MPa}$ at $850^{\circ} \mathrm{C}$. The measured YS values are also higher than reported by Chlupová et al. [10] for nearly lamellar Ti-46Al-7Nb-2Mo and Ti-46Al-7Nb-0.5C (at.\%) alloys where the compression yield strength was about 707 and $917 \mathrm{MPa}$ at RT and 485 and $693 \mathrm{MPa}$ at $800^{\circ} \mathrm{C}$, respectively. The achieved results of YS for the studied alloy are in good agreement with the yield strength reported by Gerling et al. [41], who reported tensile yield strength of about $1070 \mathrm{MPa}$ at RT for the Ti-45Al-5Nb-0.5C (at.\%) alloy prepared by powder metallurgy and rolling. However, the authors also noted a significant drop in the yield strength at temperatures above $700^{\circ} \mathrm{C}$ and the yield strength only of about $200 \mathrm{MPa}$ at $950^{\circ} \mathrm{C}$. This may be primarily because the microstructure of their alloy was not fully lamellar because the fully lamellar structure has a higher brittle-ductile transition temperature.

\section{Conclusions}

The thermal stability and precipitation strengthening of fully lamellar Ti-45Al-5Nb-0.2B-0.75C (at.\%) alloy have been characterized. The following conclusions are reached:

1. Solid solution annealing at $1360^{\circ} \mathrm{C}$ for $1 \mathrm{~h}$ followed by the cooling at a constant cooling rate of $20^{\circ} \mathrm{C} \min ^{-1}$ to $850^{\circ} \mathrm{C}$ and free air cooling to room tem- perature allows preparation of a fully lamellar type of microstructure in which carbon is dissolved in the $\alpha_{2}$ and $\gamma$-phases.

2 . The dominant change in the microstructure during ageing was a gradual thinning of the $\alpha_{2}$ lamellae and formation of the discontinuous $\alpha_{2}$ segments at a higher ageing temperature and longer ageing time.

3. Besides the parallel decomposition of the $\alpha_{2}$ lamellae, the nucleation and growth of the equiaxed $\gamma$ grains along the grain boundaries and inside the lamellar grains contribute to microstructure instabilities of the studied alloy.

4. Two types of carbides are formed during ageing. P-type carbides are formed during short times of ageing on dislocations and the grain boundaries, and H-type are formed during longer ageing times in the recrystallized $\gamma$ grains, at the lamellar interfaces and inside the $\alpha_{2}$ lamellae. No H-type precipitates were observed after ageing at $750{ }^{\circ} \mathrm{C}$.

5. The needle-shaped H-type precipitates with a size up to $10 \mu \mathrm{m}$ were formed at a higher ageing temperature of 850 and $950{ }^{\circ} \mathrm{C}$ and longer ageing time.

6 . Microhardness measurements revealed that the thermal exposure caused a small increase of the microhardness during short ageing times. Longer exposure times caused the softening of alloy, but softening is slow and probably cannot affect the yield strength significantly. However, coarsening of carbides at higher temperatures appears to be problematic, because large carbides reduce ductility and deteriorate mechanical properties.

7. The yield strength of the alloy is relatively high and except RT does not show any significant changes for different ageing conditions. The yield strength of alloy shows high values even at $950^{\circ} \mathrm{C}$ and indicates the potential of the fully lamellar microstructure in combination with carbon alloying to increase the operating temperatures of the studied alloy.

\section{Acknowledgements}

This article has been elaborated in the framework of the project No. LO1203 "Regional Materials Science and Technology Centre - Feasibility Program" funded by the Ministry of Education, Youth and Sports of the Czech Republic.

\section{References}

[1] Appel, F.: Gamma Titanium Aluminide Alloys: Science and Technology. Weinheim, Wiley-VCH 2011. ISBN: 978-3-527-31525-3.

[2] Clemens, H.: Adv. Eng. Mater., 15, 2013, p. 191. doi:10.1002/adem.201200231

[3] Wu, X.: Intermetallics, 14, 2006, p. 1114. doi:10.1016/j.intermet.2005.10.019 
[4] Appel, F.: Intermetallics, 8, 2000, p. 1283. doi:0.1016/S0966-9795(00)00036-4

[5] Zeen, W.: Mater. Charact., 124, 2017, p. 1. doi:10.1016/i.matchar.2016.12.008

[6] Cegan, T.: Kovove Mater., 53, 2015, p. 69. doi:10.4149/km_2015_2_69

[7] Pelachová, T.: Kovove Mater., 53, 2015, p. 415. doi:10.4149/km_2015_6_415

[8] Kim, S-W.: Mater. Des., 54, 2014, p. 814. doi:10.1016/j.matdes.2013.08.083

[9] Appel, F.: Materials Science and Engineering R, 22, 1998, p. 187. doi:10.1016/S0927-796X(97)00018-1

[10] Chlupová, A.: Mater. Des., 99, 2016, p. 284. doi:10.1016/i.matdes.2016.03.079

[11] Maruyama, K.: Mater. Sci. Eng. A, 239-240, 1997, p. 419. doi:10.1016/S0921-5093(97)00612-6

[12] Zhang, W. J.: Mater. Sci. Eng. A, 362, 2003, p. 280. doi:10.1016/S0921-5093(03)00589-6

[13] Schwaighofer, E.: Intermetallics, 46, 2014, p. 173. doi:10.1016/j.intermet.2013.11.011

[14] Perdrix, F.: Intermetallics, 9, 2001, p. 807. doi:10.1016/S0966-9795(01)00066-8

[15] Tian, W-H.: Intermetallics, 5, 1997, p. 237. doi:10.1016/S0966-9795(96)00086-6

[16] Gouma, P. I.: Mater. Lett., 57, 2003, p. 3581. doi:10.1016/S0167-577X(03)00129-0

[17] Klein, T.: Acta Mater., 94, 2015, p. 205. doi:10.1016/i.actamat.2015.04.055

[18] Wei, Z. J.: J. Mater. Sci., 37, 2002, p. 1809.

[19] Park, Y. S.: Mater. Sci. Eng. A, 336, 2002, p. 196. doi:10.1016/S0921-5093(01)01954-2

[20] Wang, L.: Intermetallics, 89, 2017, p. 32. doi:10.1016/j.intermet.2017.05.006

[21] Wang, L.: Acta Mater., 137, 2017, p. 36. doi:10.1016/j.actamat.2017.07.018

[22] Schwaighofer, E.: Acta Mater., 77, 2014, p. 360. doi:10.1016/j.actamat.2014.06.017

[23] Lapin, J.: Mater. Des., 133, 2017, p. 404. doi:10.1016/j.matdes.2017.08.012
[24] Gabrisch, H.: Intermetallics, 33, 2013, p. 44. doi:10.1016/i.intermet.2012.09.023

[25] Wang, L.: Intermetallics, 66, 2015, p. 111. doi:10.1016/i.intermet.2015.07.001

[26] Karadge, M.: Metall. and Mater. Trans. A, 34, 2003, p. 2129. doi:10.1007/s11661-003-0277-8

[27] Cegan, T.: Mater. Tehnol., 48, 2014, p. 831.

[28] Scheu, C.: Acta Mater., 57, 2009, p. 1504. doi:10.1016/i.actamat.2008.11.037

[29] Klimová, A.: Kovove Mater., 51, 2013, p. 89. doi:10.4149/km 2013289

[30] Hecht, U.: Intermetallics, 16, 2008, p. 969. doi:10.1016/j.intermet.2008.04.019

[31] Hu, D.: Intermetallics, 6, 1998, p. 413. doi:10.1016/S0966-9795(98)80019-8

[32] Karthikeyan, S.: Intermetallics, 13, 2005, p. 985. doi:10.1016/j.intermet.2004.12.020

[33] Huang, Z. W.: Intermetallics, 54, 2014, p. 49. doi:10.1016/j.intermet.2014.05.015

[34] Beschliesser, M.: Mater. Sci. and Eng. A, 329-331, 2002, p. 124. doi:10.1016/S0921-5093(01)01545-3

[35] Kim, Y.-W.: Intermetallics, 53, 2014, p. 92. doi:10.1016/i.intermet.2014.04.006

[36] Wu, Y.: Mater. Sci. and Eng. A, 347, 2003, p. 171. doi:10.1016/S0921-5093(02)00598-1

[37] Lapin, J.: Intermetallics, 14, 2006, p. 1175. doi:10.1016/j.intermet.2005.12.013

[38] Gil, I.: Intermetallics, 9, 2001, p. 373. doi:10.1016/S0966-9795(01)00014-0

[39] Lapin, J.: Mater. Sci. and Eng. A, 360, 2003, p. 85. doi:10.1016/S0921-5093(03)00445-3

[40] Lapin, J.: Gamma Titanium Aluminide Alloys 2014: A Collection of Research on Innovation and Commercialization of Gamma Alloy Technology. Eds.: Kim, Y.-W., Smarsly, W., Lin, J., Dimiduk, D., Appel, F. Hoboken, John Wiley \& Sons, Inc. 2014.

[41] Gerling, R.: Intermetallics, 16, 2008, p. 689. doi:10.1016/j.intermet.2008.02.004 